\title{
The Swiss Debt Brake - Has It Been a Success? ${ }^{2}$
}

\author{
Tobias Beljean and Alain Geier ${ }^{\mathrm{b}}$
}

JEL-Classification: H6

Keywords: debt, debt brake, fiscal rules, Switzerland

\section{Introduction}

The Swiss seem to attach high importance to issues of fiscal responsibility. Polls tend to support the view that the Swiss people show a broad and persistent support for a prudent fiscal policy. As an example, the research institute gfs.bern (as mandated by economiesuisse) has ascertained that a majority of voters believe public debt is very high (too high for $44 \%$ of respondents) and support further fiscal rules in the area of social security. ${ }^{1}$ These figures reflect the usual outcome of votes about the general principle of sound public finances - i.e. when the discussion is not associated with specific spending items or policies.

This attitude contrasts with the evolution of public debt in the past, particularly during the 1990s (cf. Figure 1). During that time, gross federal debt rose steeply: Economic upturns were not used as an opportunity for fiscal consolidation, which resulted in consecutive large deficits during economic downturns.

This deficit bias was coupled with a pro-cyclical fiscal policy, especially during the $1990 \mathrm{~s}^{2}$ : The budget tended to be in deficit during economic upswings, as policymakers used buoyant revenues to undertake additional tasks and projects. In the following recessions they were forced to make unavoidable cuts. In other words, fiscal policy actually had the effect of reinforcing economic cycles - providing additional stimuli during booms and exacerbating recessions through fiscal tightening.

Figure 2 shows the relevant figures for the 1980s and 1990s. The upper graph of Figure 2 shows the output gap (line) and the cyclically adjusted budget deficit

a Background paper for a presentation at the conference "The Swiss Debt Brake - Ten Years on" at the Study Center Gerzensee, Switzerland, 1-2 November 2012.

b Federal Finance Administration, this paper expresses the opinion of the authors.

1 See GFS.BERN (2012).

2 e.g. Schaltegger and Weder (2010) or Lampart (2005). 
Figure 1: Gross Federal Debt (1980-2011)

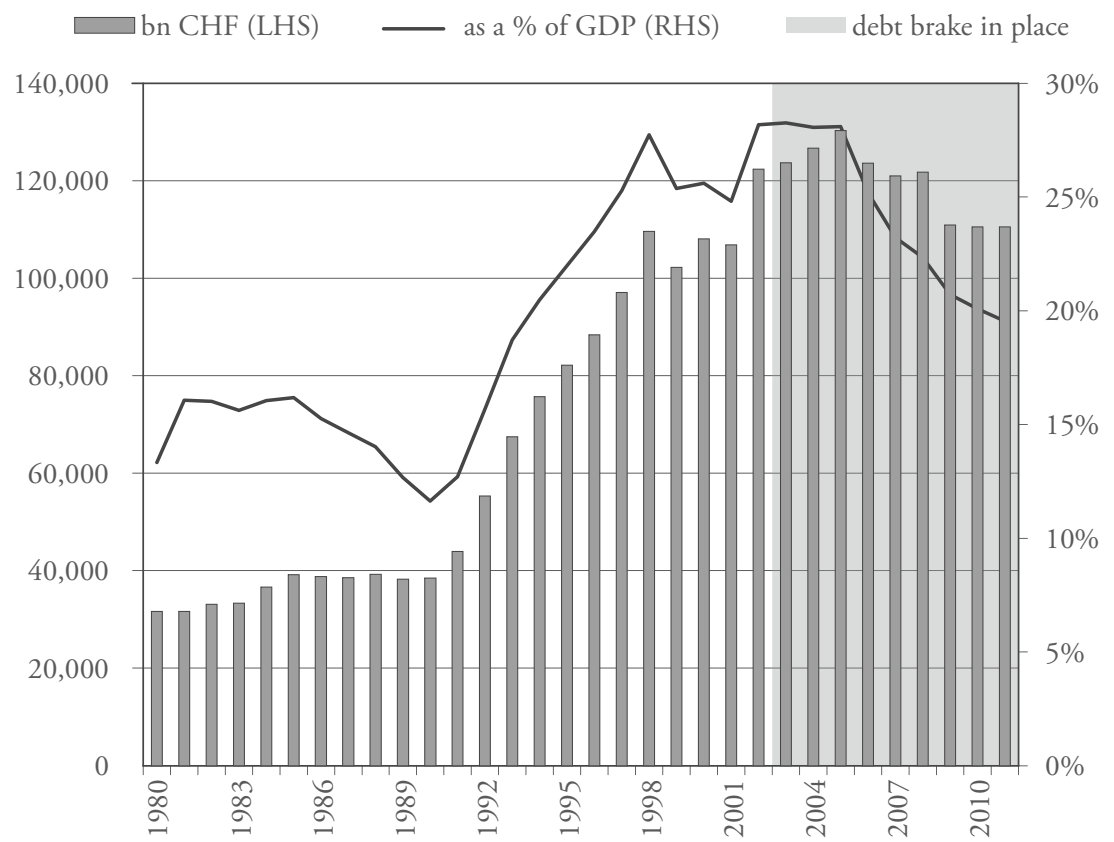

(CAB). ${ }^{3}$ This measures the part of the deficit that is not influenced by cyclically fluctuating tax revenues. The latter tend to have a naturally dampening effect on economic cycles (automatic stabilisers). It can be seen that the deficit started to soar during a boom phase with a positive output gap around 1990. When the output gap turned sharply negative after 1994 there was still a deficit, but it was being sharply cut back. The lower graph shows the change in the CAB from year to year. It is a measure of the discretionary change of fiscal policy stance (negative fiscal impulse $=$ expansive). According to this measure, the pro-cyclical stance of federal fiscal policy becomes more obvious. On political grounds, this behaviour is easily understood, as it is easier to implement a restrictive fiscal policy when the deficit is large and government debt increases quickly.

3 The cyclical adjustment for the present data was implemented with a simple adjustment of revenues, in a similar way that is implied by the debt brake formula (see Box). Loans to unemployment insurance have been excluded. 
Figure 2: Fiscal Policy Stance in \% of GDP (1980-1999)
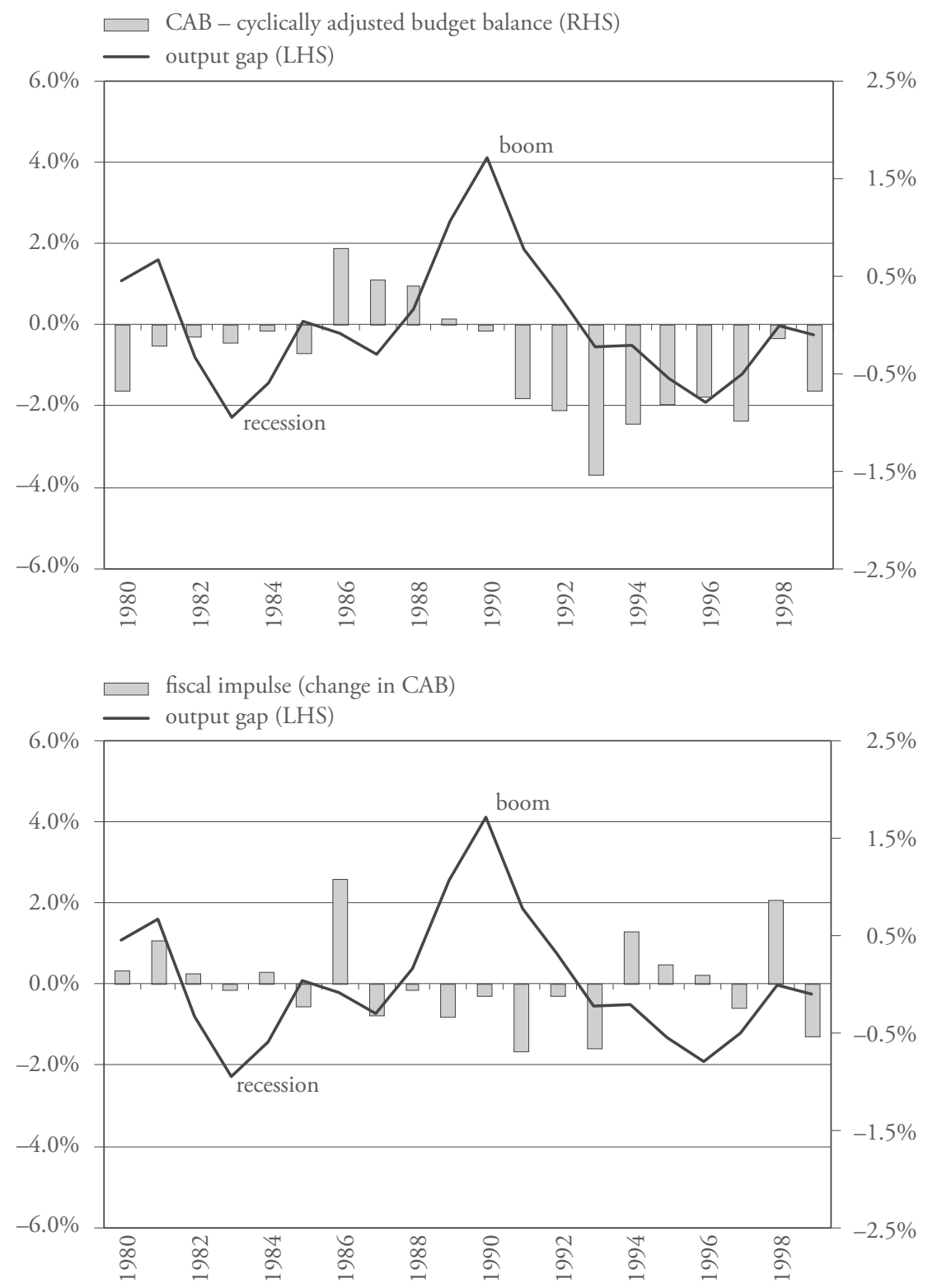
The inconsistency between this development and the attitude of the Swiss people towards fiscal policy reveals an institutional bias towards fiscal deficits. ${ }^{4}$ Fiscal rules are one possible response to a deficit bias, as they are aimed at correcting incentives in order to make fiscal policy more sustainable. Indeed, it was these developments (and demographic prospects which are likely to further increase fiscal pressures in Switzerland ${ }^{5}$ ) that led policymakers to consider the introduction of a fiscal rule - the debt brake (see Box) - which would modify the existing incentives that arise from these perceived institutional flaws of the budget process.

\section{Box: The Debt Brake in a Nutshell}

According to the Federal Constitution, the Confederation has to (1) keep income and expenditure in balance over time. The Constitution states that a (2) ceiling for total expenditure must be presented with the federal budget. This ceiling is calculated as the level of revenue, adjusted for the economic situation, which corresponds in economic terms to the cyclical position of the economy - the output gap.

This is formalised in the basic debt brake formula below, which states that in any calculation period $(t)$, the maximum allowed level of expenditures $(G)$ must equal revenues $(R)$, after multiplication by the "business cycle adjustment factor" $(k)$. This business cycle adjustment factor is aimed at stabilising expenditures around the level of cyclically adjusted revenues and consists of the ratio of (real) trend output $\left(y^{*}\right)$ and actual output $(y)$. Therefore, if the factor $k$ is larger than one, a deficit is allowed (cyclical deficit), whereas if the factor $k$ is smaller than one, a (cyclical) budgetary surplus is required:

$$
\bar{G}=k_{t} R_{t} \text { with } k_{t}=\frac{y_{t}^{*}}{y_{t}} .
$$

The Constitution also states that (3) exceptional financial requirements may justify an increase in this ceiling. The increase must be approved by a qualified majority vote in parliament and apply to a situation that is more clearly described by the specific budget law. The last but crucial feature stipulated by the Constitution is that (4) expenditure in excess of the expenditure ceiling in the (ex post) federal accounts must be compensated for in subsequent years.

\footnotetext{
See e.g. Alesina and Perotti (2008).

Federal Department of Finance (2012).

6 GeIer (2011).
} 
The debt brake first came into effect with the 2003 federal budget, having been approved by a huge majority of $85 \%$ in a preceding mandatory referendum in 2001. In 2013, the rule is about to celebrate its $10^{\text {th }}$ anniversary. This is a good opportunity to look back and ask whether it has been a success or not.

\section{A Glaringly Obvious Answer?}

At first glance, the answer is clear: Yes, of course it has been a success. Deficits have been turned into surpluses (Figure 3) and federal debt has not only ceased to rise, but has actually decreased by around CHF 12 bn from $28.2 \%$ of GDP at the end of 2002 to $19.5 \%$ in 2012 (Figure 1).

Figure 3: Cyclically Adjusted Budget Balance, CHF mn (1980-2012)*

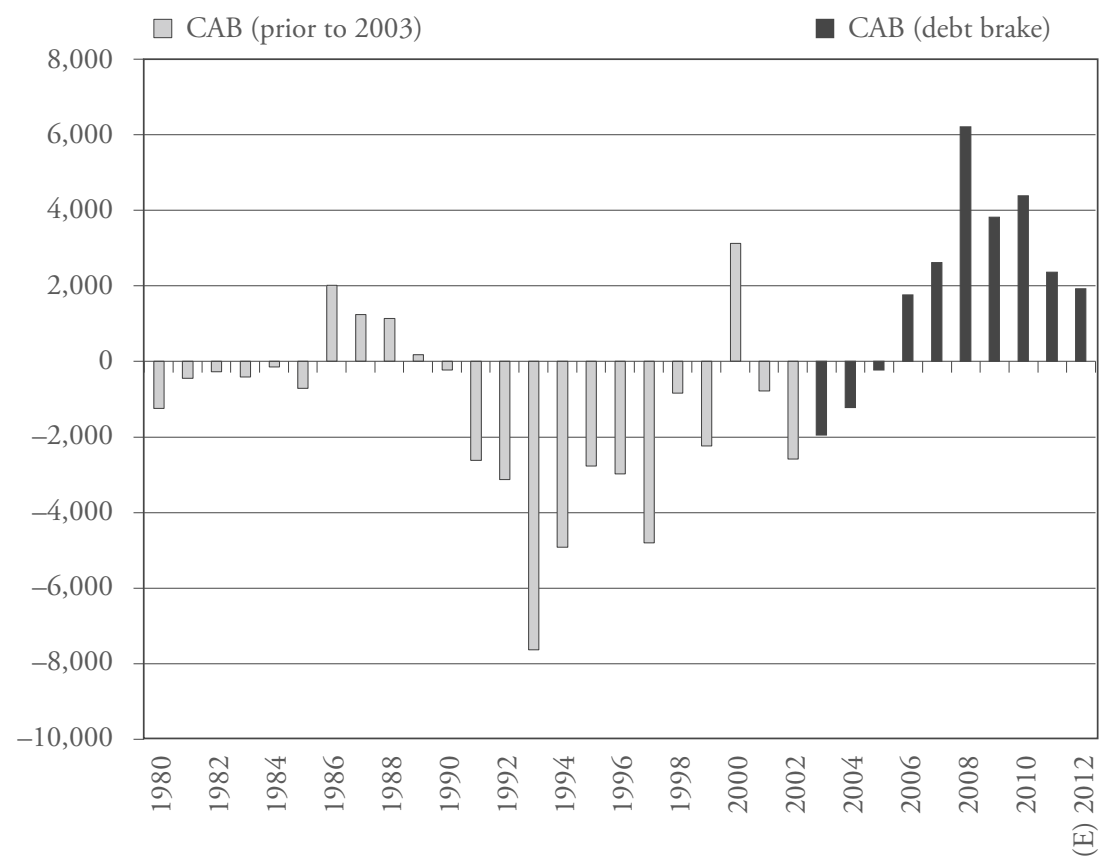

* 1980-2002: cyclically adjusted budget balance, adjusted ex post for extraordinary items. 2003-2012: cyclically adjusted ordinary budget balance. 
There is no sign of a debt crisis in Switzerland, with government bond yields currently at all-time lows and market rates for treasury bills even in negative territory. There has been an increase in fiscal space, which puts government finances in good condition to respond to adverse developments, e.g. in the financial sector or as induced by demographic changes.

Figure 3 shows that, with the exception of a short transition period with negative structural balances $(\mathrm{CABs})$, the requirements of the debt brake - a nonnegative structural balance - have been largely respected and actually exceeded.

The business cycle adjustment has prevented expenditure cuts during downturns. Although there has been no deficit in the ordinary account since 2005, the surplus was actually reduced during economic downturns.

Figure 4: Extraordinary Budget Balances, CHF mn (2002-2011)

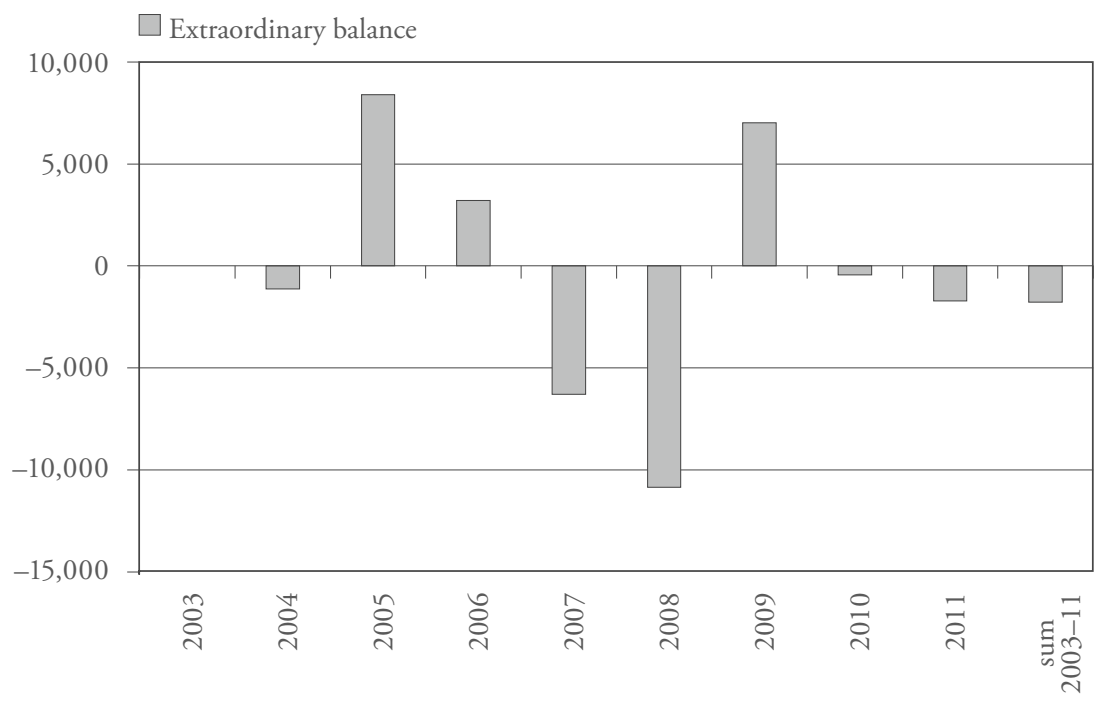

The escape clause of the debt brake allows for spending in excess of estimated cyclically adjusted revenue. The basic idea behind this is that under special circumstances - e.g. sharp recessions or unforeseeable events - the political cost of meeting the debt brake requirement may rise to the point where there is an overwhelming incentive to break it. The escape clause is a provision that effectively deals with this issue, yet without putting the rule itself at risk. A large part of extraordinary spending is the consequence of dealing with accounting issues (e.g. 
the extraordinary inflow of proceeds from gold sales in favour of the old age pension fund in 2005 and its subsequent outflow to the pension fund in 2008). In addition to extraordinary spending there are also extraordinary (one-off) revenue items that may not be used to finance spending. This gives rise to an "extraordinary budget". Figure 4 shows that the individual amounts concerned can be quite large, but their sum has led to an increase in debt by only CHF 1.8 bn, which was more than compensated for by the structural surpluses in the ordinary budget. Despite having been criticised as a possible loophole and having even given rise to a mandatory compensation mechanism for extraordinary spending in $2008^{7}$, the escape clause has not been abused.

\section{Post Hoc, Ergo Propter Hoc? ${ }^{8}$}

Looking at these figures, the fiscal policy outcomes could hardly have been more advantageous in terms of debt stabilisation. But how instrumental was the debt brake in actually achieving this outcome? The sharp increase of public debt in the 1990s was not only due to institutional factors, but also to an extremely adverse macroeconomic environment. In addition, balance sheet transparency increased in that period, leading to the inclusion of selected items such as liabilities from the public pension fund, thereby increasing the face value of debt.

In contrast to this situation, Switzerland has experienced several years of strong growth since the introduction of the debt brake, and even recent crises have had less of an impact on growth and the budget than was originally feared and forecasted. It appears that it was quite easy to comply with the requirements of the debt brake against this background, and that it would accordingly be wrong to give all the credit for the current situation to the debt brake alone. After all, there is no way of testing how things would have turned out in the absence of the debt brake, or if economic conditions had been less favourable. However, a number of factors clearly suggest that the debt brake played a significant role.

A comparison of fiscal policy in the 1980s (leaving the special case of the 1990s aside) and the years under the debt brake regime yields the first piece of evidence: Figure 2 shows that boom phases in the 1980s were not used to make savings for a "rainy day", while the boom phase between 2005 and 2008 generated significant surpluses (Figure 3). In other words, the debt brake seemed to rein in the temptation to spend the extra revenues accumulated during "the years of plenty".

7 Federal Council (2008).

8 "After this, therefore because of this". 
Regarding the fiscal policy stance, although there have been only a few deficits since the introduction of the debt brake, the overall picture reveals that fiscal policy has been largely appropriate:

Figure 5: Fiscal Policy Stance; 1980s vs. 2000s
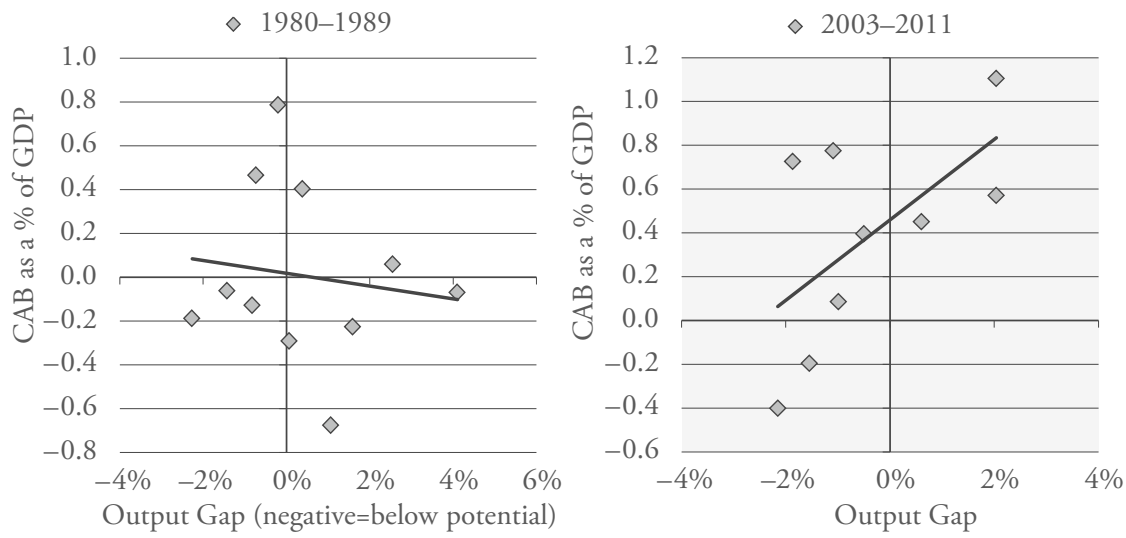

The horizontal axis in Figure 5 shows the extent of the output gap (negative $=$ below potential); the vertical axis shows the structural budget deficit (CAB) as a $\%$ of GDP (negative= deficit). Although the data set is too small to allow for statistically robust results, it makes a strong case for giving the debt brake the benefit of the doubt: The figures presented above suggest that the introduction of the debt brake has indeed changed the outcomes of fiscal policy in a way that cannot be attributed to the economic situation alone.

Another piece of evidence supporting this conclusion is the structural deficit which appeared immediately after the introduction of the debt brake in 2003 and in the aftermath of the dotcom bubble bursting (when receipts had been underestimated by CHF 4 bn). In order to comply with the fiscal rule, a consolidation plan ("EP 03") $)^{9}$ was quickly introduced, to be followed by another set of measures two years later ("EP 04") ${ }^{10}$. These measures were unable to restore conformity with the rule immediately, but did eventually restore structural equilibrium

9 Federal Council (2003).

10 Federal Council (2005). 
to an extent and with the speed that would hardly have been conceivable before the introduction of the debt brake.

There is no doubt that the above-mentioned results would have been much harder to achieve under harsher economic conditions, such as those that prevailed in the 1990s. But the success is not just visible in figures - it is also evident in the way that the budget process has changed.

The debt brake has turned the budget process upside down. Previously, spending intentions were submitted by individual government offices, and it was very difficult to make changes to a large number of budget items during the short interval between the first consolidated budget plan (largely influenced by government offices) between April and the final budget proposal in June. More problematic still, the finance minister faced the potential opposition of six "spending" ministers, who were each looking for support to get their policy proposals into the budget. The budget process is now essentially a top-down process, in which targets are set at the beginning of the process and then broken down to individual ministries and offices.

There is a substantial body of literature explaining how bargaining in a coalition government and other factors create an institutional incentive towards deficits. ${ }^{11}$ The debt brake seems to have diminished the effect of these factors and given the finance minister a tool to enforce fundamental budgetary targets. One key aspect is the fact that the debt brake sets a clear target for the deficit and expenditure. The discussion on how this target should be set from a technical perspective may be relevant, but it is less crucial than the existence of the target itself.

The debt brake has also strengthened the medium-term perspective of fiscal policy: The financial plans (for the three years following the budget year) may not be subject to the debt brake, but the rule nonetheless represents a strong incentive to make those years meet the requirements of the debt brake at an early stage. When financial plan years are presented, they either already comply with the debt brake, or they indicate the necessary consolidation amount with the planned strategy. Furthermore, the government defines medium-term expenditure growth targets for the main task areas in order to set priorities and pre-empt deviations from the rule.

11 See Von Hagen (1992) and Kopits and Symanski (1998). 


\section{Is the Target Appropriate?}

Assessing the success of the debt brake requires us to go beyond the analysis of deficit and debt, because it measures the success of the debt brake by targets imposed by the debt brake itself. The target value of the debt brake is a balanced cyclically adjusted budget. This means that nominal debt is not allowed to rise over the course of the economic cycle. Economic literature and different fiscal rules provide a good basis for comparing the current set-up with alternative targets. One alternative would be to stabilise the debt ratio, which would be less restrictive than the current target. However, it should be remembered that the rule was intentionally designed to be ambitious not only because it was feared that extraordinary spending would be higher, but also in anticipation of looming demographic challenges. ${ }^{12}$ In actual fact, the result has so far been more restrictive than intended, as has been made clear above. This outcome has often been welcomed by policymakers, however, since it provides more fiscal leeway to tackle unanticipated challenges. Furthermore, lower debt service expenditure related to the reduction of debt has allowed other expenditure to be increased by roughly CHF 1 bn since 2003.

In addition to the target being more or less restrictive, one could also envisage a change to the scope of the rule. So far, the expenditure ceiling encompasses all spending within financial accounts, including investment spending. While it makes sense to cover recurrent investment spending with revenue, it could be argued that peaks of investment should be debt-financed at the beginning and compensated for through subsequent surpluses - a provision called "golden rule". Such a provision would create a loophole, however, as the definition of investment spending is not always clear and would be open to debate. For example, public accounting does not consider education spending to be investment spending, although in economic terms this would make some sense. A reasoning on similar lines could be applied to other spending items, however, and eventually lead to a weakening of the rule. As investment spending at federal level is relatively low compared with local government budgets and investment peaks are rare (and often financed through special purpose funds), it was decided that investment spending should be subject to the rule.

As regards the consideration of the business cycle, the target also depends on technical parameters such as the method used to calculate the output gap. This is done by smoothing the real GDP series using a statistical filter (modified HP

12 DANninger (2002).

13 Compare Bruchez (2003). 
filter $\left.^{13}\right)$. The filter method is applied to 24 annual data points using a "smoothness parameter" of 100 , which is the result of simulations using different values (BRUCHEz, 2003). The elasticity of revenues with respect to GDP is assumed to be unitary ${ }^{14}$, which is consistent with empirical tests (Colombier, 2003).

An explicit objective behind the design of the debt brake was to keep the abovementioned parameters simple and transparent. A more sophisticated approach might lead to marginal improvement - with no guarantee, however - while creating an unintelligible black box for policymakers and voters who might quickly lose confidence in the calculations of the expenditure ceiling. The technical implementation may not be perfect, but this would also be the case for any conceivable alternative. Moreover, the chosen parameters have been extensively tested from theoretical points of view and in several simulations. An obvious case for alternative parameters has never been made, neither from within nor from outside the administration (although some adaptations were implemented in $2003^{15}$ ). The success of the rule with respect to the fiscal policy stance generally confirms the choices that were made ten years ago.

For the sake of intellectual honesty, one aspect of the debt brake is problematic from a theoretical point of view and has already technically led to a temporary breach of the rule: Any structural deficit must be eliminated within the upcoming budget, i.e. immediately. In 2003, the rule was introduced in spite of a (unexpected) remaining structural deficit. However, it was neither politically feasible nor desirable from the point of view of macroeconomic policy to eliminate the deficit at once. Instead, an "adjustment path" for expenditure was adopted that allowed for a gradual elimination of the deficit up to 2006. This procedure seems sensible, but was not explicitly a provision of the debt brake. This aspect is the consequence of the debt brake being fundamentally a deficit rule, not an expenditure rule. Similarly, existing literature on fiscal rules points out the advantage of expenditure rules over budget rules with respect to the (short-term) stability of fiscal policy (DaBAn et al., 2003). More recent proposals generally take the view that a fiscal rule should incorporate elements of both types (Debrun et al., 2008; Kumar et al., 2009).

14 The coefficient $\mathrm{k}$ (see box, equation) is implicitly raised to the power of one. In case of a different elasticity, $\mathrm{k}$ should be raised to the power of that elasticity.

15 Federal Council (2003). 


\section{How Has the Target Been Achieved?}

The scope of a fiscal rule lies on a macro level, with its target value being the cyclically adjusted - budget balance. Only aggregate expenditure and receipts are directly concerned by the rule. Its rationale also lies in the political economy of the budget process as a whole. At the same time, however, the rule must be implemented on a micro level, i.e. through the adjustment of individual budget items. It is therefore reasonable to question the impact of these adjustments on different types of spending areas, i.e. the impact on "budget quality". Has the rule led to increased spending cuts in the areas of investment spending or education and research? Would such an outcome be in line with policymakers' priorities?

In theory, investment spending is most at risk of becoming the target of budget consolidation. Firstly, it can be reduced easily and quickly, because it does not represent entitlement spending. Second, the impact of the cuts is not noticed immediately, since the benefits of investment accrue in the future. Nevertheless, from today's standpoint there is no indication that investment spending has suffered from the introduction of the debt brake. On average, federal investment spending has remained largely stable over the last few decades (cf. Figure 6). From the 1980 s up until 2002 , investment spending represented $12.0 \%$ of total spending on average. This figure increased to $12.2 \%$ from 2003 to 2011. In terms of GDP, investment spending has remained stable at around 1.2 to $1.3 \%$ of GDP. In addition, it should be noted that infrastructure density in Switzerland is high and has recently increased. ${ }^{16}$ It is also important to note the importance of the federal structure of Switzerland where the debt brake is concerned: many types of investment expenditure and the majority of education expenditure comes under the authority of sub-national government, i.e. it is to be found in cantonal rather than federal budgets.

A second aspect of the question of how the target was achieved concerns the deviations of effective fiscal policy outcome from the budget: The impressive track record of the first decade of the debt brake was not fully intended by policymakers ex ante, because in eight of the last nine years the actual (ex post) surpluses/deficits were higher/lower than planned (cf. Table 1). Accordingly, while budgets were structured with a view to ensuring a balanced budget on average, the actual outcomes were larger than intended structural surpluses. In fact, the debt brake did not only lead to a stabilisation of debt, but also to an outright reduction of the face value of debt.

16 BAK Basel Economics (2011). 
Table 1: Difference Between Federal Budget and Federal Accounts (Outturns)

\begin{tabular}{lccccc}
\hline (CHF mn) & 2003 & 2004 & 2005 & 2006 & 2007 \\
\hline Budget: & & & & & \\
Ordinary receipts & 50,856 & 47,944 & 50,749 & 52,157 & 56,011 \\
k-factor (output gap) & 1.006 & 1.012 & 0.997 & 0.998 & 0.991 \\
Ordinary expenditure & 51,102 & 51,410 & 52,547 & 52,743 & 55,107 \\
Budget balance & -246 & $-3,466$ & $-1,798$ & -586 & 904 \\
CAB & 59 & $-2,891$ & $-1,950$ & -690 & 400 \\
\hline Outturns: & & & & & \\
Ordinary receipts & 47,161 & 48,629 & 51,282 & 54,911 & 58,092 \\
k-factor (output gap) & 1.018 & 1.009 & 0.998 & 0.986 & 0.974 \\
Ordinary expenditure & 49,962 & 50,285 & 51,403 & 52,377 & 53,965 \\
Budget balance & $-2,801$ & $-1,656$ & -121 & 2,534 & 4,127 \\
CAB & $-1,952$ & $-1,218$ & -224 & 1,766 & 2,617 \\
\hline
\end{tabular}

\begin{tabular}{lcccc}
\hline (CHF mn) & 2008 & 2009 & 2010 & 2011 \\
\hline Budget: & & & & \\
Ordinary receipts & 57,976 & 59,968 & 58,208 & 62,423 \\
k-factor (output gap) & 0.987 & 0.995 & 1.042 & 1.013 \\
\hline Ordinary expenditure & 56,854 & 59,020 & 60,237 & 63,069 \\
Budget balance & 1,122 & 948 & $-2,029$ & -646 \\
CAB & 368 & 648 & 416 & 166 \\
\hline Outturns: & & & & \\
Ordinary receipts & 63,894 & 60,949 & 62,833 & 64,245 \\
k-factor (output gap) & 0.983 & 1.018 & 1.013 & 1.007 \\
Ordinary expenditure & 56,598 & 58,228 & 59,266 & 62,333 \\
Budget balance & 7,296 & 2,721 & 3,568 & 1,912 \\
\hline CAB & 6,210 & 3,818 & 4,384 & 2,362 \\
\hline
\end{tabular}




\section{Figure 6: Investment Spending*}

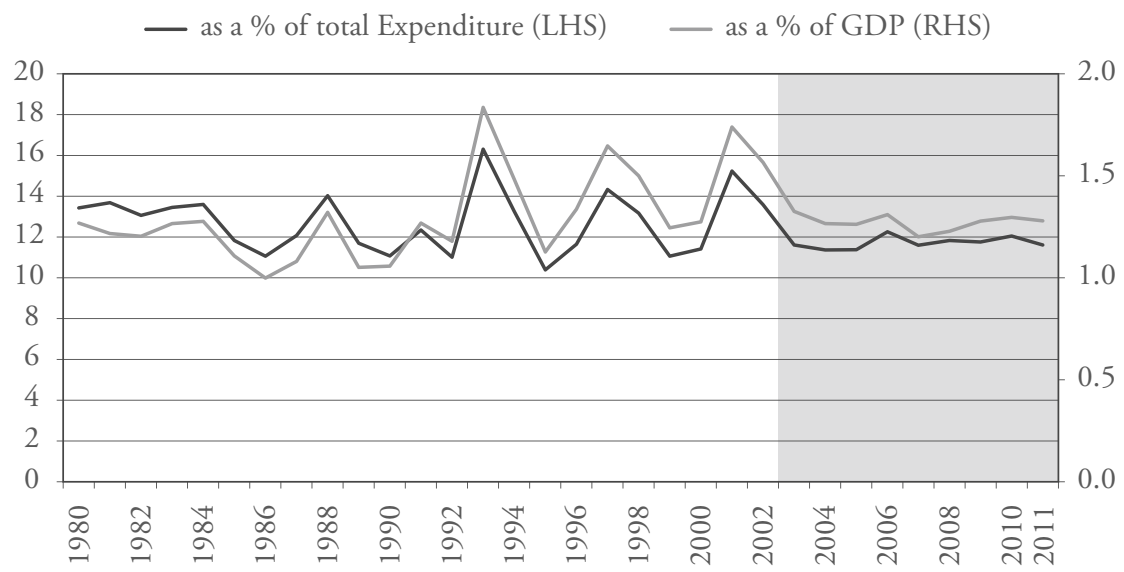

* Investment spending, adjusted for extraordinary items and loans to unemployment insurance.

Figure 7 contains a graphic illustration of the contributions to the structural surplus that was accumulated from 2003 to 2011. It shows deviations from budgeted values both on the revenue side (left-hand column) and the expenditure side (right-hand column). These figures raise the question of whether the introduction of the debt brake resulted in a deterioration of forecasting quality.

Figure 7: Origin of Surpluses: Differences Between Budgets and Accounts 2003-2011

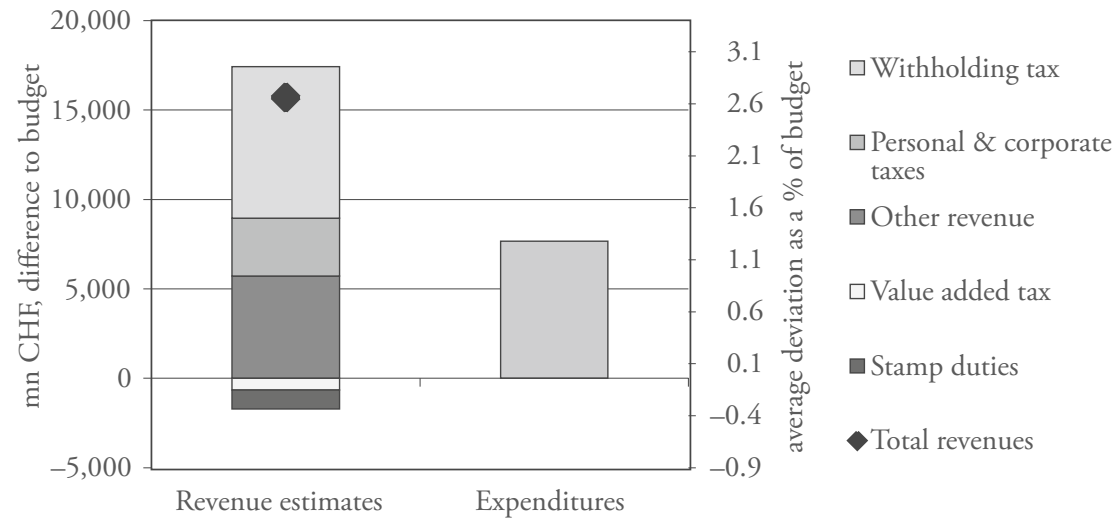

Swiss Journal of Economics and Statistics, 2013, Vol. 149 (2) 
During the period of 2003 to 2011, expenditure was underestimated by a total of around $1.5 \%$ of budgeted expenditure per year, or CHF 7.7 bn in total, thereby contributing to more than a quarter of the cumulated structural surplus. But it should be noted that this "underspending" is not a new phenomenon, and stems from the institutional framework on the micro level (which did not change with the introduction of the debt brake): On the spending side, the debt brake sets a ceiling for budgeted total expenditure. Detailed spending limits, however, are set by specified budget items (about 1,100 ), which are all approved separately by parliament in the budget bill. Increasing spending above these limits requires the approval of a supplementary credit by parliament. To avoid this exposure the (risk-averse) administration tends to plan its spending cautiously so as to not exceed the limit of the credit item. Hence, actual outcomes are mostly below spending limits and are not compensated for by occasional overspending and supplementary credits. The consequence for overall spending is a systematic undershooting of expenditure with respect to the budget.

The revenue side, on the other hand, was overestimated and has further amplified this result, although this is more difficult to analyse. A brief analysis of revenue estimates prior to the introduction of the debt brake shows that erroneous estimations have been mostly symmetric since the 1970s. Since the introduction of the debt brake, however, revenues have been regularly underestimated, and have contributed to structural surpluses even more than expenditures.

Figure 7 and Table 2 show that revenues were underestimated by an average of $2.7 \%$ of budgeted revenues between 2003 and 2011, which amounts to a total of CHF 15.7 bn during that period. A large part of this deviation is due to a single revenue item, the withholding tax. This tax is levied on dividend and interest income and can be claimed back by taxpayers upon submission of tax returns. The proceeds of the withholding tax correspond to the difference between the levied amounts and those claimed back by taxpayers. The balance between these two values is very volatile and is not correlated with economic growth. Its movements can hardly be forecasted, and even ex post explanations tend to be incomplete. During the 2003 to 2011 period, a rise in claims by taxpayers was always expected (substantial rises in claims after increases in levied taxes had been commonplace prior to the debt brake) but never actually materialised. This led authorities to underestimate withholding tax receipts by $1.4 \%$ of total revenues per annum or CHF 8.5 bn during the whole period. This accounts for some fifty per cent of the aggregate underestimation of receipts, although withholding tax represents only a modest share of aggregate revenues (7.6\%).

The main revenue sources of the Confederation, namely VAT (34.3\%) and personnel and corporate taxes (28.3\%), exhibit average estimation errors which 
Table 2: Differences Between Budgets and Accounts: Underestimation of Revenues

Actual ordinary outcomes vs. budgeted values, $\%$ of budget

\begin{tabular}{|c|c|c|c|c|c|c|c|}
\hline & 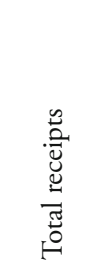 & 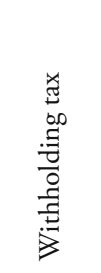 & 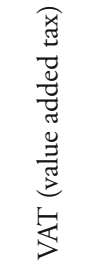 & 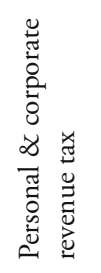 & 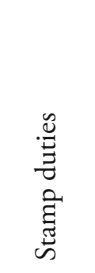 & 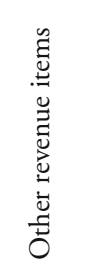 & 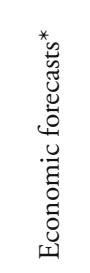 \\
\hline 2003 & $-7.8 \%$ & $-4.8 \%$ & $-1.2 \%$ & $-1.4 \%$ & $-1.4 \%$ & $0.9 \%$ & $-3.1 \%$ \\
\hline 2004 & $1.4 \%$ & $-0.2 \%$ & $-0.1 \%$ & $0.6 \%$ & $-0.5 \%$ & $1.6 \%$ & $0.9 \%$ \\
\hline 2005 & $1.0 \%$ & $1.9 \%$ & $0.0 \%$ & $-0.3 \%$ & $-1.2 \%$ & $0.6 \%$ & $0.1 \%$ \\
\hline 2006 & $5.0 \%$ & $1.7 \%$ & $1.0 \%$ & $0.8 \%$ & $0.2 \%$ & $1.3 \%$ & $3.0 \%$ \\
\hline 2007 & $3.6 \%$ & $2.1 \%$ & $0.1 \%$ & $0.4 \%$ & $-0.4 \%$ & $1.4 \%$ & $5.7 \%$ \\
\hline 2008 & $9.3 \%$ & $5.4 \%$ & $0.1 \%$ & $1.8 \%$ & $0.1 \%$ & $1.9 \%$ & $3.9 \%$ \\
\hline 2009 & $1.6 \%$ & $2.2 \%$ & $-2.2 \%$ & $0.3 \%$ & $0.3 \%$ & $0.9 \%$ & $-5.3 \%$ \\
\hline 2010 & $7.4 \%$ & $2.7 \%$ & $0.7 \%$ & $2.2 \%$ & $0.3 \%$ & $1.3 \%$ & $2.8 \%$ \\
\hline $2011^{* *}$ & $2.8 \%$ & $1.8 \%$ & $0.3 \%$ & $0.5 \%$ & $0.2 \%$ & $0.0 \%$ & $0.2 \%$ \\
\hline Avg. 03-11 & $2.7 \%$ & $1.4 \%$ & $-0.1 \%$ & $0.6 \%$ & $-0.3 \%$ & $1.1 \%$ & $0.9 \%$ \\
\hline \multicolumn{8}{|c|}{ Pro memoria: share of total proceeds from different revenue items (2011): } \\
\hline 2011 & $100.0 \%$ & $7.6 \%$ & $33.8 \%$ & $27.8 \%$ & $4.5 \%$ & $26.3 \%$ & n.a. \\
\hline
\end{tabular}

* The figure shows the estimated share of the change of output gap and inflation revisions in the revenue difference, i.e. revisions in economic forecasts contributed to an underestimation of revenues by $0.9 \%$ p.a. (CHF 5.1 bn in total) out of a total of $2.7 \%$ p.a. (CHF 15.7 bn in total) between 2003 and 2011.

** 2011 = provisional.

are noticeably smaller, however. Since these two taxes are closely linked to economic activity, the deviation can be explained mainly by revisions in economic forecasts, which account for an underestimation of revenues by $0.9 \%$ per year, or a total of CHF 5.1 bn during the period as a whole (cf. last column in Table 1). It should nonetheless be noted that VAT is biased by an "outlier" in 2009.

Withholding tax and business cycle effects together account for the lion's share of the total underestimation. The business cycle effect is visible in revenue items such as personnel and corporate taxes, as well as VAT. Stamp duties, on the other hand, experienced a structural erosion of their tax base during the period in 
question. Furthermore, it is interesting to see that a number of other taxes, most notably non-fiscal revenue, were underestimated by the relatively large amount of $1.1 \%$ per year on average, even though - like the withholding tax - they do not closely correlate with the business cycle.

Taken together, the expenditure and the revenue side led to an underestimation of budget outcomes by roughly CHF 23 bn from 2003 to 2011, which corresponds to $4.1 \%$ of GDP. ${ }^{17}$ However, there is no guarantee that future developments will be similar to those in the described period. The underestimation of revenue may well be reversed if conditions within the economy or the financial sector change. From a statistical point of view, the error in revenue forecasts was not significantly above zero either in the period 1990-2011 or indeed in the period 2003-2011. In the meantime, the forecasting methods for withholding tax and non-fiscal revenue have been revised by the Federal Department of Finance. It therefore appears reasonable to assume that the revenue-side bias will not continue unabated in the long run. As regards the expenditure side, the overestimation tendency described above seems to be a factor inherent in the system, and is therefore likely to lead to further structural surpluses and reductions of debt in future. While this non-utilised fiscal space is often criticized, one should not forget that lower debt entails permanently lower debt servicing costs, thereby increasing fiscal space in the future.

\section{The Institutional Context of the Debt Brake}

Last but not least, an evaluation of the debt brake must consider the entire institutional setting of fiscal policy at federal level. Otherwise there is a danger that too much credit may be given to the debt brake itself: The debt brake did not fill an institutional vacuum, but was embedded in institutional parameters that have emerged gradually over a decade or more. Indeed, there are several fiscal rules at federal level that preceded the debt brake.

The "expenditure brake" was introduced in 1995 and is still in place. This constitutional rule requires a qualified majority vote in parliament for new spending items that amount to CHF 20 million or more (or CHF 2 million if the spending is to recur annually). While the expenditure brake did not turn out to be particularly effective, it did signal the rising awareness of policymakers of a need

17 As a consequence this has led to correspondingly large surpluses on the "compensation account" of the debt brake; see e.g. Bodmer (2006) or GeIER (2012) for a more detailed explanation of the debt brake mechanism. 
for "self-constraint". In 1998, a constitutional "budget target 2001" was introduced in order to eliminate the remaining structural deficit ${ }^{18}$ and thus prepare the way for the debt brake. The budget target was replaced by the debt brake two years later.

The most important fiscal institution established prior to the debt brake is the fact that the Constitution stipulates (maximum) rates for value added tax (VAT) and direct federal tax. These legal limits entail an asymmetry between revenue and spending. Increasing tax rates require a mandatory referendum, while expenditure can be increased by (for the most part) simple majority votes in parliament. This constellation of institutional parameters partly explains the deficit bias before 2003, because it created an incentive towards excessive expenditure that would only later be counteracted by the debt brake. This "revenue brake" and the "debt brake" taken together now result in a framework similar to an expenditure rule, as it is rather difficult to meet the requirements of the debt brake through revenue-side measures - at least in the short term.

As Switzerland does not have a constitutional court, there is no legal body capable of enforcing the formal budgetary requirements of the debt brake. It therefore cannot be taken for granted that fiscal rules will automatically be respected. This is where direct democracy becomes important. The initial popular vote with a strong majority in favour of the debt brake is a key factor in ensuring its credibility. This credibility is continuously reinforced by the strong public support for a cautious fiscal policy stance. It is also important to note that there is no supranational authority to enforce a fiscal policy framework in Switzerland. The debt brake is enforced through a political bottom-up channel rather than a top-down approach such as the one in place in the EU.

\section{Conclusion}

While discretionary policy has often led to outcomes that are not considered satisfactory, Switzerland and other countries are slowly gathering experience with a new type of fiscal policy, namely a rules-based type. This policy necessarily involves compromise, as different principles need to be balanced (e.g. budget authority of parliament, sustainability of public finances, flexibility, etc.). There

18 The elimination of the structural deficit has turned out to be only partial, as the extent of the structural deficit had to be revised substantially upwards during the economic slowdown in 2002 . 
is no recipe for automatic success with any kind of policy, and the debt brake should be judged not against an ideal, but against possible alternatives. From this perspective, the debt brake can be judged as a success. It has been able to trigger effective budget consolidation, thereby preventing public debt from rising further. It is thus likely to have a significant effect even in the event of economic conditions deteriorating. The debt brake enforced a tight fiscal policy in an era of favourable economic conditions. This in turn has increased fiscal space for situations in which fiscal expansion may become necessary. In the meantime, a lower public debt burden and the corresponding lower debt servicing costs have created more leeway within the budget for other types of expenditure such as education and development aid. This success is supported not just by theoretical arguments, but also by a gradually accumulating set of data.

At the same time, the question remains whether the success will hold in the face of looming large future challenges. The time horizon of the debt brake is short and may lead to increased pressure on spending items that are easy to cut from a political perspective, but do not necessarily reflect an economic optimum. Future challenges such as demographic change require special attention and have already led to calls and ideas for an extension of the fiscal rules-based approach to the social insurances ${ }^{19}$.

The implementation of the debt brake also raises questions regarding the credibility of budget forecasts and "underspending" relative to the budget. Moreover, a sudden structural downward shift in GDP and a corresponding drop in structural revenues could lead to a budget consolidation of large magnitude that would put the rule under pressure. While a case for some adaptation of the debt brake should never be ruled out, the existing mechanism has proved flexible enough so far to deal with unforeseen events.

There is good reason to be optimistic for the future: The crucial advantage of a rules-based fiscal policy is the separation of the debate over principles - such as changing the rule's objectives - from the debate about specific expenditure projects. It has always proved difficult to conduct both discussions at the same time and arrive at a satisfactory conclusion, and this remains the case in areas where there is no rules-based approach, e.g. in the area of social security. The debt brake has changed the way fiscal policy is conducted in a promising manner.

19 E.g. Economiesuisse (2008) and Bruchez and Matter (2011). 


\section{References}

Alesina, Alberto, and Roberto Perotti (1995), “The Political Economy of Budget Deficits", IMF Staff Papers, 42, pp. 1-31.

BAK Basel (2011), Erreichbarkeit als Standortfaktor: Globale und Kontinentale Erreichbarkeit im Jahr 2010, Öffentlicher Bericht zur Projektphase 2011.

Bodmer, Frank (2006), "The Swiss Debt Brake: How it Works and What Can Go Wrong", Swiss Journal of Economics and Statistics, 142(3), pp.307-330.

Brennan, Geoffrey, and James M. Buchanan (1985), The Reason of Rules: Constitutional Political Economy, New York: Cambridge University Press.

Bruchez, Pierre-Alain (2003), «Réexamen du calcul du coefficient k», Swiss Federal Finance Administration, Working Paper 2.

Bruchez, Pierre-Alain, and Eva Matter Schaffner (2011), «Des règles budgétaires pour les assurances sociales", La Vie économique 1/2-2011.

Colombier, Carsten (2003), „Der Zusammenhang zwischen dem Bruttoinlandsprodukt und den Schweizer Bundeseinnahmen“, Swiss Federal Finance Administration, Working Paper 5.

Dabàn, Teresa, Enrica Detragiache, Gabriel di Bella, Gian Maria Milesi-Ferretti, and Steven Symansky (2003), "Rules-Based Fiscal Policy in France, Germany, Italy and Spain”, IMF Occasional Paper, 225.

Danninger, Stephan (2002), "A New Rule: 'The Swiss Debt Brake'”, IMF Working Paper, 02/18.

Debrun, Xavier, Natan P. Epstein, and Steven A. Symansky (2008), "A New Fiscal Rule: Should Israel Go Swiss?”, IMF Working Paper 08/87.

Economiesuisse (2008), Nachhaltige Finanzpolitik für Wachstum und Wohlstand. Federal Council (2000), „Botschaft zur Schuldenbremse vom 5. Juli 2000“, Bundesblatt 2000, 35, pp. 4653-4726.

Federal Council (2001), „Zusatzbericht zur Botschaft zur Schuldenbremse vom 10. Januar 2001“, Bundesblatt 2001, 24, pp. 2387-2420.

Federal Council (2003), „Botschaft zum Entlastungsprogramm EP 03 vom 2. Juli 2003“, Bundesblatt 32, pp. 5615-5802.

Federal Council (2005), „Botschaft zum Entlastungsprogramm EP 04 vom 8. Februar 2005“, Bundesblatt 5, pp. 5615-5802.

Federal Council (2008), Botschaft über die Ergänzungsregel zur Schuldenbremse vom 19. September 2008, Bundesblatt 2008, 42, pp. 8491-8540.

Federal Department of Finance (2012), Report on the Long-Term Sustainability of Public Finances in Switzerland.

Geier, Alain (2011), "The Debt Brake - the Swiss Fiscal Rule at the Federal Level”, Federal Finance Administration, Working Paper 15. 
Grs Bern (2012), Schlussbericht zum „Finanzmonitor 2012“, Studie im Auftrag von economiesuisse.

von Hagen, Jürgen (1992), "Budgeting Procedures and Fiscal Performance in the European Community", in: Commission of the European Community, Economic Papers, 96.

Kopits, George, and Steven A. Symansky (1998), "Fiscal Policy Rules", IMF Occasional Paper 162.

Kumar, Manmohan, Emanuele Baldacci, Andrea Schaechter, Carlos Caceres, Daehaeng Kim, Xavier Debrun, Julio Escolano, Jiri Jonas, Philippe Karam, Irina Yakadina and Robert Zymek (2009), Fiscal RulesAnchoring Expectations for Sustainable Public Finances, Washington.

Lampart, Daniel (2005), „Die konjunkturelle Ausrichtung der Schweizer Finanzpolitik im internationalen Vergleich“, KOF Working Papers, 109.

Schaltegger, Christoph A., and Martin Weder (2010), „Fiskalpolitik als antizyklisches Instrument? Eine Betrachtung der Schweiz", Perspektiven der Wirtschaftspolitik, 11(2), pp. 146-177.

\section{SUMMARY}

This paper describes how the Swiss fiscal rule at federal level has fared since it was introduced in 2003. Generally speaking, the rule has modified the budget process and led to a better implementation of fiscal policy objectives. It is argued that the most important factor is the existence of a binding ceiling for expenditure. The design of the mechanism is important in setting the right incentives. A basic feature of the rule is its simplicity and transparency. It is argued that an increase in sophistication would eliminate this advantage without guaranteeing preferable outcomes. It appears that the rule has contributed to a substantial reduction in nominal debt. This outcome has occurred against the backdrop of a favourable economic situation (which was not anticipated) and is primarily attributable to an underestimation of both revenues and economic growth. Nominal debt reduction may not materialise to the same extent under different circumstances. It appears that systematic underspending with respect to the budget leads to a bias towards budget surpluses. In addition, there has been no visible reduction in the quality of budget composition, and the fiscal policy stance as measured by the change in the cyclically adjusted budget balance has been appropriate given the prevailing economic conditions. While some design features may be debatable, the overall rules-based approach to fiscal policy has been successful. 